\title{
Safety Evaluation of Diethyl Citrate and Its Impact on Vascular Calcification
}

\author{
Chao-yang DUAN ${ }^{1}$, Ling-hong HUANG ${ }^{2}$, Da GUO ${ }^{2}$, Jian-ming \\ OUYANG ${ }^{2, b}$, Jin HAN ${ }^{1}$ and Bao-song GUI ${ }^{1, a, *}$ \\ ${ }^{1}$ Department of Nephrology, the Second Hospital of Xi'an Jiaotong University, Xi'an \\ 710004, China \\ ${ }^{2}$ Department of Chemistry, Jinan University, Guangzhou 510632, China \\ aguibsdoctor@sina.com, btoyjm@jnu.edu.cn \\ ${ }^{*}$ Corresponding author
}

Keywords: Anticoagulation, Vascular calcification, Acute toxicity.

\begin{abstract}
To investigate the inhibitory effects of diethyl citrate $\left(\mathrm{Et}_{2} \mathrm{Cit}\right)$ on calcification, $\mathrm{Et}_{2} \mathrm{Cit}$ was given to animals (SD rats) of the vascular calcification model. The results showed that $\mathrm{Et}_{2} \mathrm{Cit}$ is safety and non-toxic by intraperitoneal administration. Compared with control group, $\mathrm{Et}_{2} \mathrm{Cit}$ can reduce tail artery pressure and significantly reduce the calcium salt of vascular membrane elastic fibers on aortic Von Kossa staining. $\mathrm{Et}_{2} \mathrm{Cit}$ has anti-vascular calcification effect and has no side effect. This result will help to provide a new research direction and theoretical basis for the prevention and treatment of vascular calcification.
\end{abstract}

\section{Introduction}

Vascular calcification (VC) is attributed to the passive precipitation of calcium phosphate in arterial walls and described as a strictly regulated, active, preventable, and reversible biological process similar to bone formation [1,2]. Increases in extracellular calcium and phosphate levels stimulate the transition of vascular smooth muscle cells (VSMCs) from a contractile phenotype to an osteochondrogenic phenotype and thus form pro-calcifying matrix vesicles (MVs) that can nucleate hydroxyapatite [3-5]. In this process, the expression of calcification inhibitors, such as matrix Gla protein (MGP), osteopontin (OPN), and calcium-sensitive receptor (CaSR), is downregulated, whereas the expression of calcification-promoting factors, such as alkaline phosphatase (ALP) and osteocalcin, is upregulated [6,7].

$\mathrm{VC}$ in patients with cardiovascular disease (CVD) are classified into arterial intima calcification, arterial media calcification (AMC), and calcific uremic arteriolopathy; AMC, which is also known as Mönckeberg's sclerosis, is typically observed in hemodialysis patients [8]. Hyperphosphatemia, hypercalcemia, and high calcium phosphate $(\mathrm{Ca} \times \mathrm{Pi})$ products are closely related to the occurrence of these calcifications $[9,10]$. VC occurs because of the passive precipitation of Ca phosphate and resembles an active process similar to bone formation [11]. Increases in extracellular $\mathrm{Ca}$ and phosphate levels stimulate the transdifferentiation of vascular smooth muscle cells (VSMCs) into an osteochondrogenic phenotype, trigger vesicle release, induce apoptosis, and promote further calcification [12].

Hemodialysis as a kind of extracorporeal circulation technology, need to use proper anticoagulant, to prevent blood clotting in the dialyzator and dialysis pipeline. In the process of dialysis, sodium citrate $\left(\mathrm{Na}_{3} \mathrm{Cit}\right)$ not only can bind with calcium ion to form 
calcium citrate, which is difficult to dissociate, but also can reduce blood calcium. However, it causes the shortcomings of hypocalcaemia, hypematremia and metabolic alkalosis when the calcium ions were reduced.

To improve the disadvantage of $\mathrm{Na}_{3} \mathrm{Cit}$, we previously designed and synthesized diethyl citrate ( $\mathrm{Et}_{2} \mathrm{Cit}$ ). In vivo, compared with sodium citrate, diethyl citrate dissociates with calcium more rapidly, the time of anticoagulation is more fit for blood purification, and a low incidence of hypocalcaemia.

We have examined the thermodynamic features, including stoichiometry, stability constant, thermodynamic functions, and anticoagulant properties, of the $\mathrm{Ca}^{2+}$ complex with $\mathrm{Et}_{2} \mathrm{Cit}$ [13-15]. Our experimental results have indicated that $\mathrm{Et}_{2} \mathrm{Cit}$ as an anticoagulant can alleviate hypercalcemia, hypernatremia, and metabolic alkalosis in hemodialysis patients. It has been proved that citrate acid can prevent from vessels, pericardium and valvular calcification. So it's worth noting that whether the diethyl citrate plays a role in the prevention and treatment of vascular calcification.

This article was to study the stability and safety of diethyl citrate can provide relevant information about its shelf life and storage environment, we observe the reaction of acute toxicity and learn the effect of diethyl citrate on the prevention and treatment of vascular calcification by animal experiment. To obtain the parameters and classification of acute toxicity, we secondly observe the performance of poisoning, the intensity of toxic effects, death time and number of animals, and clarify the characteristics of the dose-response relationship and drug side-effect. Lastly we observe the effcet of diethyl citrate on vascular calcification. All these researches can provide new research direction and theoretical basis for studying clinical drug of vascular calcification tharapy.

\section{Materials and Methods}

\section{Reagents and Apparatus}

Mouse aortic smooth muscle cells (MOVAS) were purchased from Shanghai Cell Bank, Chinese Academy of Sciences. Diethyl citrate $\left(\mathrm{Et}_{2} \mathrm{Cit}\right)$ was synthesized in our laboratory [13]. It was analyzed by elemental analysis, infrared spectroscopy, mass spectrometric analysis and nuclear magnetic resonance. The purity was determined by thin layer chromatography and acid titration. The mass fraction of $\mathrm{Et}_{2} \mathrm{Cit}$ was $99.27 \%$.

\section{Acute Toxicity Test of Animals}

Animal test was processed by a Up-and-Down Procedure. In this procedure, each time an animal was given drug. If this animal survived, the second animal was given a high-level doses. If the first animal died or nearly died, the second animal was given a low-level doses.

Method of drug delivery: An intraperitoneal injection was used for drug delivery. The details are as follow: Seven healthy female mice were chosen, each weighing 18 22 g. All the mice were offered by the medical school animal experiment center of Xi'an Jiaotong University.

The mice were randomly divided into 7 groups and each group one mouse was used. The control group only received physiological saline. The other six groups received varying amounts of $\mathrm{Et}_{2} \mathrm{Cit}$ according to Table 1, respectively. After injection of $\mathrm{Et}_{2} \mathrm{Cit}$, each mouse was carefully observed and recorded. Two times for the first day, and then one time every day. This observation continued to the $14^{\text {th }}$ days. The following content was observed and recorded carefully: the time appearance and disappearance of the 
toxic effects for each animal, breathing, autonomic activity, and behavior of the central nervous system and so on. The weight of the mice was weighed at 1 week before and after drug administration. All animals should be carried out an autopsy and the abnormal organ should be carried out histopathology.

\section{Potential Treatments of Vascular Calcification in an Animal Model}

The experimental SD rats, weighing between $150 \mathrm{~g}$ and $180 \mathrm{~g}$, were obtained from the experimental animal center of Peking University Health Science Center and used in the present study. The body weight, tail pulse pressure, cardiac mass, and Von Kossa staining in aorta were measured as the index of calcification in the present study.

The rats were randomly divided into three groups: Group I: control group. Group II (model group), the vascular calcification model was produced by vitamin D3 (300 $\mathrm{klU} / \mathrm{kg}$ ) plus nicotine ( $25 \mathrm{mg} / \mathrm{kg}, 5 \mathrm{ml} / \mathrm{kg}$ ). Group III (experimental group), on the basis of calcification model, the tail vein was injected with $\mathrm{Et}_{2} \mathrm{Cit} 5 \mathrm{ml}$ (soluble in $0.9 \%$ sodium chloride solution). Treatment was given 6 days per week for 4 weeks.

\section{Results and Discussion}

\section{Results of Acute Toxicity Test of Animals}

The experimental results for each group are shown in Table 1. For the control group mouse, no significant adverse effect was observed. Its activity was normal and no mortality. For the mice of medicine groups, when the amount of $\mathrm{Et}_{2} \mathrm{Cit}$ was less than 6.9 $\mathrm{g} / \mathrm{kg}$, the activities of mice were not significantly reduced and not death occurred.

When the dose of $\mathrm{Et}_{2} \mathrm{Cit}$ was increased $9.9 \mathrm{~g} / \mathrm{kg}$, a reduced activity, ataxia, slow and sluggish and other adverse reactions immediately occurred, but still no animal died. But these side effects can disappear within 1 hour when the amount of the dose $\leq 9.9 \mathrm{~g} / \mathrm{kg}$.

There were no significant difference of the weight of mice between the experimental animal and the control group during the experiment. No significant lesions of the body tissues and organs were observed by macroscopic observation at the end of experiment.

According to the standard fixed dose method [2] made by the British Society of Toxicology in 1984 [14], the results showed that no animal was died, it indicates that the $\mathrm{Et}_{2} \mathrm{Cit}$ without serious risk of acute poisoning (Table 2).

Table 1. Experimental results of toxicity test of $\mathrm{Et}_{2} \mathrm{Cit}(\mathrm{n}=1)$

\begin{tabular}{|l|l|l|l|}
\hline $\begin{array}{l}\text { Mouse } \\
\text { coding }\end{array}$ & $\begin{array}{l}\text { Dose of } \\
\mathrm{Et}_{2} \text { Cit / mg }\end{array}$ & $\begin{array}{l}\text { Mouse } \\
\text { weight/g/kg }\end{array}$ & Mouse reaction \\
\hline 1 & 0 & 0 & Normal activities, no death \\
\hline 2 & 94 & 4.9 & $\begin{array}{l}\text { No significant reduction of activity; no appearance of } \\
\text { unsteady gait, slow; no slack, shortness of breath and } \\
\text { jump; no death }\end{array}$ \\
\hline 3 & 129 & 5.9 & Ibid \\
\hline 4 & 161 & 6.9 & Ibid \\
\hline 5 & 190 & 7.9 & $\begin{array}{l}\text { Activity reduction, accompanied by unsteady gait, slow, } \\
\text { sluggish, shortness of breath and jump; no death }\end{array}$ \\
\hline 6 & 208 & 8.9 & Ibid \\
\hline 7 & 258 & 9.9 & Ibid \\
\hline
\end{tabular}

\section{Potential Treatments of Vascular Calcification in an Animal Model}

Compared with control group, the results showed that $\mathrm{Et}_{2} \mathrm{Cit}$ can reduce tail artery pressure, also can significantly reduce the calcium salt of vascular membrane elastic fibers on aortic Von Kossa staining (Table 3), and had no obvious influence between 
body weight and cardiac coefficient in the animal model of the vascular calcification (Table 4).

Table 2. Experimental results of toxicity test of $\mathrm{Et}_{2} \mathrm{Cit}(\mathrm{n}=1)$

\begin{tabular}{|c|c|c|c|}
\hline \multirow{2}{*}{$\begin{array}{l}\text { Dose } \\
/ \mathrm{mg} / \mathrm{kg}\end{array}$} & \multicolumn{3}{|l|}{ Experimental results } \\
\hline & Survive several $<100 \%$ & $\begin{array}{l}100 \% \text { live shows } \\
\text { obviously toxicity }\end{array}$ & $\begin{array}{l}100 \% \text { live without obvious } \\
\text { poisoning performance }\end{array}$ \\
\hline 5 & $\begin{array}{l}\text { Very toxic (LD50 } \leq 25 \\
\mathrm{mg} / \mathrm{kg} \text { ) }\end{array}$ & $\begin{array}{l}\text { Toxic } \\
\text { (LD50 25-200 mg/kg) }\end{array}$ & Test with $50 \mathrm{mg} / \mathrm{kg}$ \\
\hline 50 & $\begin{array}{l}\text { With high toxic or toxic, } \\
\text { test with } 5 \mathrm{mg} / \mathrm{kg}\end{array}$ & $\begin{array}{l}\text { Harmful } \\
\text { (LD50 200-2000 mg/kg) }\end{array}$ & Test with $500 \mathrm{mg} / \mathrm{kg}$ \\
\hline 500 & $\begin{array}{l}\text { Toxic or harmful, } \\
\text { test with } 50 \mathrm{mg} / \mathrm{kg}\end{array}$ & $\mathrm{LD} 50>2000 \mathrm{mg} / \mathrm{kg}$ & Test with $2000 \mathrm{mg} / \mathrm{kg}$ \\
\hline 2000 & Test with $500 \mathrm{mg} / \mathrm{kg}$ & The compound without $\mathrm{s}$ & us risk of acute poisoning \\
\hline
\end{tabular}

Table 3. Effect of Et2Cit on tail artery pressure in rats (unit: $\mathrm{mmHg}$ )

\begin{tabular}{|c|c|c|c|c|}
\hline Group & 1 week & 2 weeks & 3 weeks & 4 weeks \\
\hline I- $\mathrm{Na}_{3}$ Cit & $112 \pm 6$ & $106 \pm 5$ & $110 \pm 7$ & $117 \pm 5$ \\
\hline II- ferric citrate & $113 \pm 7$ & $113 \pm 7^{*}$ & $119 \pm 8^{*}$ & $127 \pm 5^{*}$ \\
\hline III- Et 2 Cit & $116 \pm 7$ & $112 \pm 9$ & $111 \pm 6^{\#}$ & $118 \pm 7^{\#}$ \\
\hline
\end{tabular}

Compared with control group, *: $P<0.05$; compared with the model group \#: $P<0.05$

Table 4. Effect of Et2Cit on cardiac coefficient in rats

\begin{tabular}{|l|l|l|l|}
\hline Group & Heart mass $/ \mathrm{mg}$ & Body weight $/ \mathrm{g}$ & Heart coefficient $\mathrm{mg} / \mathrm{g}$ \\
\hline $\mathrm{I}-\mathrm{Na}_{3}$ Cit & $1107 \pm 101.7$ & $308.9 \pm 21.0$ & $3.62 \pm 0.33$ \\
\hline II- ferric citrate & $1092.7 \pm 89.8$ & $302.6 \pm 14.8$ & $3.63 \pm 0.24$ \\
\hline III- $\mathrm{Et}_{2}$ Cit & $1061.8 \pm 102.2$ & $302.2 \pm 20.8$ & $3.48 \pm 0.30$ \\
\hline
\end{tabular}

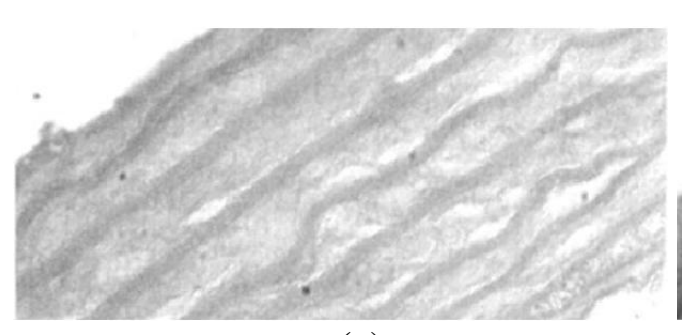

(a)

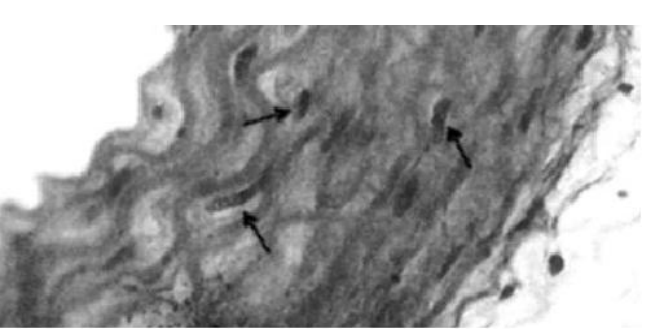

(b)

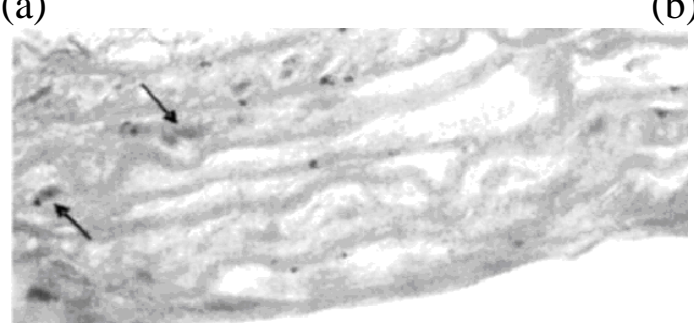

(c)

Figure 1. Von Kossa staining in rat aorta (×320). (a) Group I; (b) Group II; (c) Group III.

Vascular calcification experiment: Its impact on rat body weight and hemoglobin, phosphorus, calcium concentration, alkaline phosphatase, etc. which inclusive sodium citrate, iron citrate and diethyl citric: compared with the control group, weight, hemoglobin and alkaline phosphates, calcium, phosphorus concentration did not changed significantly in the group of vascular calcification. $(\mathrm{P}>0.05$, the difference was not statistically significant). Compared with model group body weight, hemoglobin and alkaline phosphates, calcium, phosphorus concentration did not changed 
significantly in the remaining groups during the four weeks. $(\mathrm{P}>0.05$, the difference was not statistically significant).

Von Kossa staining results showed that all the sodium citrate, ferric citrate and $\mathrm{Et}_{2} \mathrm{Cit}$ groups have the role of anti-vascular calcification (Figure 1).

\section{Conclusions}

$\mathrm{Et}_{2} \mathrm{Cit}$ has anti-vascular calcification effect and has no side effect. It is safety and non-toxic. This result provides a new research direction and theoretical basis for the prevention and treatment of vascular calcification.

\section{Acknowledgement}

This research was supported by the National Science Foundation (NO. 81570673).

\section{References}

[1] D. Ricci, L. Panicali, M. G. Facchini, E. Mancini, Citrate anticoagulation during continuous renal replacement Therapy, Contrib. Nephrol. 190 (2017) 19-30.

[2] R. Shroff, D. A. Long., C. Shanahan, Mechanistic insights into vascular calcification in CKD, J. A m. Soc. Nephrol. 24(2013) 179-189.

[3] L. Hénaut, C. Boudot, Z. A. Massy, I. Lopez-Fernandez, S. Dupont, A. Mary, T. B. Drüeke, S. Kamel, M. Brazier, R. Mentaverri, Calcimimetics increase CaSR expression and reduce mineralization in vascular smooth muscle cells: mechanisms of action, Cardiovasc. Res. 101 (2014) 256-265.

[4] J. Buturovic-Ponikvar, Is regional citrate anticoagulation the future of hemodialysis? Ther. Apher. Dial. 20 (2016) 234-239.

[5] W. R. Clark, X. Ding, H. Qiu, Z. Ni, P. Chang, P. Fu, J. Xu, M. Wang, L. Yang, J. Wang, C. Ronco, Renal replacement therapy practices for patients with acute kidney injury in China, PLoS One 12 (2017) e0178509.

[6] N. J. Paloian, E. M. Leaf, C. M. Giachelli, Osteopontin protects against high phosphate-induced nephrocalcinosis and vascular calcification, Kidney Int. 89 (2016) 1027-1036.

[7] C. L. Meuwese, H. Olauson, A. R. Qureshi, J. Ripsweden, P. Barany, C. Vermeer, N. Drummen, P. Stenvinkel, Associations between thyroid hormones, calcification inhibitor levels and vascular calcification in end-stage renal disease, PLoS One 10(2015) e0132353.

[8] R. Shroff, D. A. Long, C. Shanahan, Mechanistic insights into vascular clcification in CKD, J. A m. Soc. Nephrol. 24 (2013) 179-189.

[9] A. P. Sage, J. Lu, Y. Tintut, L. L. Demer, Hyperphosphatemia-induced nanocrystals upregulate the expression of bone morphogenetic protein-2 and osteopontin genes in mouse smooth muscle cells in vitro, Kidney Int. 79(2011) 414-422.

[10] C. P. Kovesdy, O. Kuchmak, J. L. Lu, K. Kalantar-Zadeh, Outcomes associated with serum calcium level in men with non-dialysis-dependent chronic kidney disease, Clin. J. Am. Soc. Nephro. 5 (2010) 468-476. 
[11] L. Louvet, J. Büchel, S. Steppan, J. Passlick-Deetjen, Z. A. Massy, Magnesium prevents phosphate-induced calcification in human aortic vascular smooth muscle cells, Nephrol. Dial. Transplant. 28(2013) 869-878.

[12] K. A. Lomashvili, X. Wang, R. Wallin, W. C. O’Neill, Matrix Gla protein metabolism in vascular smooth muscle and role in uremic vascular calcification, J. Biol. Chem. 286 (2011) 28715-28722.

[13] Y. Ou, J. Han, B. Chen, B. S. Gui, F. X. Wang, Y. M. Ding, J. Tan, J. M. Ouyang, Synthesis and characterization and anticoagulant properties of diethyl citrate, Asian J. Chem. 24 (2012) 4953-4960.

[14] Y. Ou, B. Chen, H. Peng, B. S. Gui, X. Q. Yao, J. M. Ouyang, Thermodynamic features of diethyl citrate calcium complexes and factors affecting the complex stability, Asian J. Chem. 24(2012) 4717-4722.

[15] J. Han, J. F. Xue, M. Xu, B. S. Gui, L. Kuang, J. M. Ouyang, Coordination dynamics and coordination mechanism of a new type of anticoagulant diethyl citrate with Ca2+ ions, Bioinorg. Chem. Appl. 2013 (2013). 